\title{
EFFECT OF NITROGEN FERTILIZATION UNDER PLASTIC AND STRAW MULCHED CONDITIONS ON CROP YIELD AND WATER USE EFFICIENCY IN MAIZE-WHEAT ROTATION
}

\author{
JAVED, A. ${ }^{1 *}-$ IQBAL, M. ${ }^{1}-$ FAROOQ, M..$^{2,3}$ \\ ${ }^{1}$ Institute of Soil and Environmental Sciences, University of Agriculture, Faisalabad, Pakistan \\ ${ }^{2}$ Department of Agronomy, University of Agriculture, Faisalabad, Pakistan \\ ${ }^{3}$ Department of Crop Sciences, College of Agricultural and Marine Sciences, Sultan Qaboos \\ University, Al-Khoud 123, Oman \\ *Corresponding author \\ e-mail:atifjavednns@gmail.com
}

(Received $9^{\text {th }}$ Feb 2018; accepted $1^{\text {st }}$ Nov 2018)

\begin{abstract}
Field experiments were conducted to find out the best optimization strategy for nitrogen and mulching for high yield and water use efficiency (WUE) of maize and wheat. Three nitrogen practices (250 kg Nha ${ }^{-1}$ for maize and $120 \mathrm{~kg} \mathrm{Nha}^{-1}$ for wheat in single split, $200 \mathrm{~kg} \mathrm{Nha}^{-1}$ for maize and $100 \mathrm{~kg}$ $\mathrm{Nha}^{-1}$ for wheat in two and three splits) and two mulches (plastic film and straw mulch) were tested. Maximum maize grain yield was recorded in $T_{5}$ (plastic film + nitrogen in three splits) which was 75.6 and $81.4 \%$ higher over control in 2014 and 2015 respectively. $\mathrm{T}_{6}$ (straw mulch + nitrogen in three splits) increased wheat grain yield by $40.7 \%$ and $46.9 \%$ in 2014 and 2015 respectively. The highest WUE of maize $\left(11.0 \mathrm{~kg} \mathrm{ha}^{-1} \mathrm{~mm}^{-1}\right.$ in 2014 and $12.4 \mathrm{~kg} \mathrm{ha}^{-1} \mathrm{~mm}^{-1}$ in 2015) and wheat $\left(8.0 \mathrm{~kg} \mathrm{ha}^{-1} \mathrm{~mm}^{-1}\right.$ in 2014 and $\left.9.0 \mathrm{~kg} \mathrm{ha}^{-1} \mathrm{~mm}^{-1} 2015\right)$ were recorded in $\mathrm{T}_{5}$ and $\mathrm{T}_{6}$ plots respectively. $\mathrm{T}_{6}$ increased soil water contents and storage by increasing soil active carbon and decreasing bulk density. In conclusion, nitrogen ( $200 \mathrm{~kg} \mathrm{ha}^{-1}$ for maize and $100 \mathrm{~kg} \mathrm{ha}^{-1}$ for wheat) applied in three splits under straw mulched conditions is preferred optimization.
\end{abstract}

Keywords: mulch, nitrogen management, soil water storage, total water use, water use efficiency

\section{Introduction}

In regions with sufficient nutrients and water inputs, nutrient and water use efficiency (WUE) of maize (Zea mays L.) and wheat (Triticum aestivum L.) are still low because of suboptimal management (Vitousek et al., 2009) which results in their increased losses (Liu et al., 2014a). Wheat and maize are important cereals that account for $\sim 70 \%$ of the world cereal production but limited water and nutrients availability are significantly affecting their yields especially in arid and semi-arid regions. However, food production will need to be doubled to feed the growing world population of 7.5 billion in 2017 which is expected to be 9.8 billion in 2050 (UN, 2017). Thus, use of limited natural resources (e.g. nutrient, water and land) will be under increasing pressure, and improving efficient use of water and nutrients for major cropping systems is a high priority (Green et al., 2010). Low productivity in semi-arid regions (like Pakistan) is due to poor soil water retention and low water-holding capacity caused by low soil organic matter (SOM) and coarse texture (Ahmad et al., 2014). To maintain normal water supply for crops with high water demand (i.e., maize) is a major challenge. Therefore, shortage in water availability is threatening the sustainability and production of major crops (Farooq and Nawaz, 2014). 
The irrigation and fertilization are the two major factors around the world to obtain high grain yields. Heavy rates of nitrogen are applied to wheat and maize crops (100200 and 200-350 kg ha ${ }^{-1}$, respectively) to support productive agriculture (Khan et al., 2007) because of poor $\mathrm{N}$ contents and inherently low organic carbon of agricultural soils in Pakistan. Scheduled application of nitrogen with irrigation events can enhance nitrogen availability to plants because undue $\mathrm{N}$ and water use in agriculture degrades environment as well as potentially threaten the sustainability of the system (Fang et al., 2010). Practices effective in conserving soil water include using suitable mulches, adding organic materials, and growing cover crops. Mulching has good potential in improving crop production by increasing soil water storage (Qureshi et al., 2010). Both straw and plastic mulching can play an important role in increasing crop and water productivity. Under warmer climate of Pakistan, plastic film mulch is more beneficial than straw mulch for improving water holding capacity and WUE (Jabran et al., 2015). Pervaiz et al. (2009) concluded that mulching significantly increased soil water and SOM content and decreased soil bulk density and soil strength. Use of rice husk vis-avis polyethylene mulch has a great potential of water saving with comparable growth and yield of wheat in the sub-tropical climatic and soil conditions (Chakraborty et al., 2008).

The amount of water used by plants is low in many cases even if the mulches are applied well. The reason for low water use by plants might be the poor fertility status of soils especially $\mathrm{N}$ (Li et al., 2000, 2009). There are various studies on effect of nitrogen fertilizers in many arid to semi-arid regions of the world, but most of the studies focuses on effect of nitrogen fertilizers on crop growth (Liu et al., 2010), its effect on crop yield and quality (Meng et al., 2012), groundwater pollution, its accumulation in soil and effects on the environment (Huai et al., 2009), but not on effect of nitrogen under mulched conditions on water use efficiency of crops. Crop yield and quality are determined by the management of nitrogen in any cropping system. Understanding the fate of applied nitrogen is vital for designing any optimal strategy for nitrogen management.

Mulches act as a barrier affecting the heat and energy transfer between atmosphere and soil and thus affect the hydrothermal properties of soil. Therefore, covering the soil with mulch may affect the fate and movement of nitrogen fertilizer in the plant-soil system and the management strategies of nitrogen for mulched and unmulched cropping systems should be different (Kettering et al., 2013). Soil chemical and biological processes such as $\mathrm{C}$ and $\mathrm{N}$ mineralization are significantly affected by mulching due to changes in soil temperature (Kader et al., 2017). Differences in water and $\mathrm{N}$ input levels, soil characteristics, climatic conditions (temperature and rainfall) and crop species lead to contrasting effects of mulching. Effects of mulching on crop yields and WUE can differ because of differences in water regime and environmental factors which require a quantitative and systematic assessment under site-specific conditions. Therefore, interactive effects between $\mathrm{N}$ fertilizer and mulches are important to understand as many soil processes and properties are affected by mulch.

This led to made us hypothesize that yield and WUE of maize and wheat crops could be improved by managing rate and timing of nitrogen under different mulched conditions. Therefore, present study was conducted with the aim to find out the best optimization strategy for nitrogen and soil surface mulching to obtain high yield and WUE of maize and wheat crops. The findings achieved will be used to optimize nitrogen fertilizers under mulched conditions to improve grain yield and WUE of maize 
and wheat crops in study area and areas with similar climatic conditions and cropping system.

\section{Materials and methods}

\section{Experimental site}

The field experiments using maize-wheat rotation were conducted for two years (2014 and 2015) at experimental station of the Institute of Soil and Environmental Sciences, University of Agriculture, Faisalabad, Punjab, Pakistan $\left(31^{\circ} \mathrm{N}, 73^{\circ} \mathrm{E}\right)$. The climate of Faisalabad is subtropical and semi-arid, with the mean maximum temperature of $41{ }^{\circ} \mathrm{C}$ and the minimum of $27^{\circ} \mathrm{C}$ during the summer. In winter these temperatures are 21 and $6{ }^{\circ} \mathrm{C}$, respectively. The average annual precipitation is $380 \mathrm{~mm}$, of which about half is received during July and August. Table 1 represents the meteorological conditions of the maize and wheat growing seasons during 2014-15 and 2015-16. The soil is derived from alluvial deposits mixed with loess and classified as a, well-drained Hafizabad loam, a mixed, semi-active, isohyperthermic Typic Calciargids (Soil Survey Staff, 2014). Soil properties at the experimental site are summarized in Table 2.

Table 1. Meteorological conditions of maize and wheat growing seasons at experimental site in Faisalabad, Pakistan. (Source: Agricultural Meteorological Cell, Department of Agronomy, University of Agriculture Faisalabad, Pakistan)

\begin{tabular}{c|c|c|c|c|c|c}
\hline \multirow{2}{*}{ Months } & \multicolumn{4}{|c|}{ Mean temperature $\left({ }^{\circ} \mathbf{C}\right)$} & \multicolumn{2}{c}{ Total rainfall (mm) } \\
\cline { 2 - 6 } & \multicolumn{2}{|c|}{ Maximum } & \multicolumn{2}{c}{ Minimum } & \multicolumn{2}{c}{} \\
\cline { 2 - 5 } & $\mathbf{2 0 1 4 - 1 5}$ & $\mathbf{2 0 1 5 - 1 6}$ & $\mathbf{2 0 1 4 - 1 5}$ & $\mathbf{2 0 1 5 - 1 6}$ & $\mathbf{2 0 1 4 - 1 5}$ & $\mathbf{2 0 1 5 - 1 6}$ \\
\hline August & 37.1 & 35.9 & 27.3 & 26.7 & 4.8 & 48.4 \\
September & 33.9 & 35.4 & 24.5 & 24.4 & 140.2 & 75.2 \\
October & 31.3 & 32.2 & 19.1 & 19.1 & 3.6 & 14.5 \\
November & 26.3 & 27.1 & 11.5 & 12.1 & 10.0 & 8.8 \\
December & 18.5 & 21.8 & 5.9 & 7.2 & 0.0 & 0.0 \\
January & 16.6 & 17.3 & 6.9 & 7.7 & 12.2 & 13.1 \\
February & 22.0 & 23.3 & 11.1 & 9.3 & 20.5 & 7.8 \\
March & 24.5 & 26.8 & 13.6 & 15.6 & 67.9 & 66.7 \\
April & 33.2 & 34.3 & 20.7 & 20.2 & 32.8 & 5.6 \\
\hline
\end{tabular}

Temperatures are monthly averages and rainfalls are monthly total

\section{Treatments and experimental design}

The crop varieties used were 'Syngenta-8611' and 'AARI-2011' for maize and wheat, respectively. Seven treatments were tested including nitrogen and mulch omission plots $\left(\mathrm{T}_{0}\right)$ and three nitrogen management practices and two mulched conditions. The treatments for the experiments for both crops were as follows:

$\mathrm{T}_{0}=$ Control (No mulch, no nitrogen)

$\mathrm{T}_{1}=$ Plastic film + nitrogen in single split $\left(\mathrm{N}_{1}\right)$

$\mathrm{T}_{2}=$ Straw mulch + nitrogen in single split $\left(\mathrm{N}_{1}\right)$

$\mathrm{T}_{3}=$ Plastic film + nitrogen in two splits $\left(\mathrm{N}_{2}\right)$

$\mathrm{T}_{4}=$ Straw mulch + nitrogen in two splits $\left(\mathrm{N}_{2}\right)$ 
$\mathrm{T}_{5}=$ Plastic film + nitrogen in three splits $\left(\mathrm{N}_{3}\right)$

$\mathrm{T}_{6}=$ Straw mulch + nitrogen in three splits $\left(\mathrm{N}_{3}\right)$

The nitrogen management details for each treatment are given in Table 3. The plots were arranged in a randomized complete block (RCB) design with three replications using a plot size of $5.5 \times 13.5 \mathrm{~m}$.

Table 2. Physico-chemical properties of soil used for study in Faisalabad, Pakistan

\begin{tabular}{c|c}
\hline Soil properties & Value \\
\hline Sand (\%) & $40 \pm 2.3$ \\
Silt (\%) & $37.5 \pm 1.0$ \\
Clay (\%) & $22.5 \pm 1.8$ \\
Textural class & Loam \\
ECe $\left.(\mathrm{dS} \mathrm{m})^{-1}\right)$ & $1.48 \pm 0.06$ \\
pH & $8.05 \pm 0.04$ \\
Field capacity $\left(\mathrm{cm}^{3} / \mathrm{cm}^{3}\right)$ & $0.29 \pm 0.03$ \\
Bulk density $\left(\mathrm{Mg} \mathrm{m}^{-3}\right)$ & $1.41 \pm 0.06$ \\
Soil organic matter $(\%)$ & $0.72 \pm 0.14$ \\
Total nitrogen $(\%)$ & $0.03 \pm 0.01$ \\
Available phosphorus $\left(\mathrm{mg} \mathrm{kg}^{-1}\right)$ & $6.1 \pm 1.3$ \\
Extractable potassium $\left(\mathrm{mg} \mathrm{kg}^{-1}\right)^{*}$ & $168.6 \pm 6.4$ \\
\hline
\end{tabular}

*Extracted with $1 \mathrm{~N}$ ammonium acetate $\left(\mathrm{NH}_{4} \mathrm{OAc}\right)$. Values are shown as mean \pm standard deviation $(\mathrm{n}=3)$

Recommended rates of phosphorus ( $150 \mathrm{~kg} \mathrm{ha}^{-1}$ for maize and $85 \mathrm{~kg} \mathrm{ha}^{-1}$ for wheat) and potassium (150 kg ha ${ }^{-1}$ for maize and $65 \mathrm{~kg} \mathrm{ha}^{-1}$ for wheat) were applied as basal dressing. While nitrogen was applied as per treatment as side dressing. For two splits nitrogen was applied to maize at sowing and 12-leaf stage (V12) and for three splits nitrogen was applied at sowing, 4-leaf stage (V4) and 12-leaf stage (V12). For wheat nitrogen was applied at sowing and crown root stage in two splits and at sowing, crown root stage and tillering stage in three splits. Table 4 presents the details on sowing dates, plant populations, and levels of irrigation and fertilizers. After 7-10 days of seedling emergence, mulches were applied in between the crop rows. It allowed plants to grow normally and rainwater to enter the soil. Rice straw (C 53.3\%, N 0.63\% and C/N 84.6) was applied at the rate of $5 \mathrm{Mg} \mathrm{ha}^{-1}$. White plastic film with $60 \mathrm{~cm}$ width and $0.008 \mathrm{~mm}$ thickness was used. Plastic film was stable and not decomposed after crop harvest.

\section{Data collection and statistical analysis}

Soil volumetric water contents $(\mathrm{SWv}, \%)$ in $0-160 \mathrm{~cm}$ depth at $20 \mathrm{~cm}$ intervals were measured at sowing and harvesting and during growing seasons at every 7 days with Time Domain Reflectometry (TDR, Model 6050X1 Trase System, Soil Moisture Equipment Corp. California, USA) between crop rows in each plot (Topp et al., 1980). Soil water storage (SWS, $\mathrm{mm}$ ) in $0-160 \mathrm{~cm}$ soil depth was calculated using following relationship:

$$
\operatorname{SWS}(\mathrm{mm})=\operatorname{SWv}(\%) \times 1(\mathrm{~mm})
$$

where ' 1 ' is soil depth. 
Table 3. The rates of nitrogen applied for each nitrogen treatment to maize and wheat crops

\begin{tabular}{c|c|c}
\hline Treatments & Maize & Wheat \\
\hline $\mathrm{N}_{1}$ & $250 \mathrm{~kg} \mathrm{ha}^{-1}($ basal $)$ & $120 \mathrm{~kg} \mathrm{ha}^{-1}(\mathrm{basal})$ \\
$\mathrm{N}_{2}$ & $200 \mathrm{~kg} \mathrm{ha}^{-1}(50: 50)$ & $100 \mathrm{~kg} \mathrm{ha}^{-1}(50: 50)$ \\
$\mathrm{N}_{3}$ & $200 \mathrm{~kg} \mathrm{ha}^{-1}(40: 30: 30)$ & $100 \mathrm{~kg} \mathrm{ha}^{-1}(40: 30: 30)$ \\
\hline
\end{tabular}

Bracket values indicate percent of total nitrogen applied per split

Plant height was measured with a meter rod from base to tip of the top most fully opened leaf of plants from each plot selected randomly. The mean plant height was expressed in cm. Formula reported by Dwyer and Stewart (1986) was used to measure the leaf area index (LAI):

$$
\text { LAI }=\text { Leaf length } \times \text { leaf width } \times \text { A }
$$

where ' $A$ ' is a factor with values of 0.80 and 0.75 for wheat and maize crops, respectively. LAI was recorded at silking stage for maize and booting stage for wheat by measuring the length and width of plant leaves from each plot selected randomly. After harvesting total biomass for each plot was measured in $\mathrm{kg}$ by using the spring balance having $20 \mathrm{~kg}$ capacity with division $0.2 \mathrm{~g}$ and precision of $+0.3 \%$ (C.K. 6202, Carl Kammerling International, UK). The straw yield was reported at $0 \%$ moisture for both crops and expressed in $\mathrm{Mg} \mathrm{ha}^{-1}$. Grain yield of both crops was noted and converted into $\mathrm{Mg} \mathrm{ha}^{-1}$ for each experimental unit. Grain yield was expressed at $14 \%$ moisture content for maize and 13\% moisture for wheat according to grain quality standards for commercial trade. Following formula was used to calculate total water use (TWU) for both crops (Ram et al., 2013):

$$
\operatorname{TWU}(\mathrm{mm})=\mathrm{I}+\mathrm{P}+\Delta \mathrm{W}+\mathrm{CR}-\mathrm{D}-\mathrm{R}
$$

where TWU is the total water use during both crops; $\mathrm{P}$ is the total precipitation; $\mathrm{I}$ is the amount of irrigation applied; $\Delta \mathrm{W}$ is the change in soil water content from sowing to harvesting in 0 to $160 \mathrm{~cm}$ depth; $\mathrm{R}$ is the surface runoff; $\mathrm{D}$ is the drainage; $\mathrm{CR}$ is the capillary rise to the root zone (Zhang et al., 2005; Su et al., 2007). Drainage and capillary rise were considered as negligible and not taken in the calculations. The drainage was considered negligible based on the assumption that irrigation water applied was equal to the soil field capacity. The WUE was calculated using following formula:

$$
\text { WUE }\left(\mathrm{kg} \mathrm{ha}^{-1} \mathrm{~mm}^{-1}\right)=\frac{\text { Grain yield }\left(\mathrm{kg} \mathrm{ha}^{-1}\right)}{\text { Total water use }(\mathrm{mm})}
$$

Core samples with $50 \mathrm{~mm}$ internal diameter were also taken from each plot for bulk density determination. Cores were placed in oven at $105^{\circ} \mathrm{C}$ for $24 \mathrm{~h}$ and bulk density was calculated by dividing the oven dried mass to the volume of core (Blake and Hartge, 1986). Soil samples from $0-15 \mathrm{~cm}$ and $15-30 \mathrm{~cm}$ were also taken for active carbon concentrations. Biologically active carbon was determined by spectrophotometer after extraction with $0.02 \mathrm{M}$ potassium permanganate (Weil et al., 2003). 
ANOVA (analysis of variance) techniques were used to statistically analyze the collected data for field trials according to RCB design. Tukey's HSD (Honestly significant difference) test at $P \leq 0.05$ was used for mean comparison (Steel et al., 1997). For statistical analysis, the software packages IBM SPSS statistics 21 was used.

Table 4. Sowing methods, plant populations, irrigation and fertilizers rate of maize-wheat crops for different treatments from 2014 to 2016

\begin{tabular}{|c|c|c|c|c|c|c|c|c|c|}
\hline \multirow{2}{*}{ Crops } & \multirow{2}{*}{ Treatments } & \multicolumn{2}{|c|}{ Sowing date } & \multirow{2}{*}{$\begin{array}{l}\text { Sowing } \\
\text { method }\end{array}$} & \multirow{2}{*}{$\begin{array}{c}\text { Plant } \\
\text { population } \\
\left(10^{4} \text { ha }^{-1}\right)\end{array}$} & \multirow{2}{*}{$\begin{array}{c}\text { Irrigation } \\
(\mathrm{mm})\end{array}$} & \multicolumn{3}{|c|}{ Fertilizer rate $\left(\mathrm{kg} \mathrm{ha}^{-1}\right)$} \\
\hline & & 2014 & 2015 & & & & $\mathbf{N}$ & $\mathbf{P}_{2} \mathrm{O}_{5}^{* *}$ & $\mathbf{K}_{2} \mathbf{O}^{* *}$ \\
\hline \multirow{7}{*}{ Maize } & $\mathrm{T}_{0}$ & Aug. 8 & Aug. 11 & Direct & 300 & 490 & 0 & 150 & 100 \\
\hline & $\mathrm{T}_{1}$ & Aug. 8 & Aug. 11 & Direct & 300 & 490 & $250^{*}$ & 150 & 100 \\
\hline & $\mathrm{T}_{2}$ & Aug. 8 & Aug. 11 & Direct & 300 & 490 & $250^{*}$ & 150 & 100 \\
\hline & $\mathrm{T}_{3}$ & Aug. 8 & Aug. 11 & Direct & 300 & 490 & 200 & 150 & 100 \\
\hline & $\mathrm{T}_{4}$ & Aug. 8 & Aug. 11 & Direct & 300 & 490 & 200 & 150 & 100 \\
\hline & $\mathrm{T}_{5}$ & Aug. 8 & Aug. 11 & Direct & 300 & 490 & 200 & 150 & 100 \\
\hline & $\mathrm{T}_{6}$ & Aug. 8 & Aug. 11 & Direct & 300 & 490 & 200 & 150 & 100 \\
\hline \multirow{7}{*}{ Wheat } & $\mathrm{T}_{0}$ & Dec. 10 & Dec. 14 & Direct & 6.0 & 300 & 0 & 85 & 65 \\
\hline & $\mathrm{T}_{1}$ & Dec. 10 & Dec. 14 & Direct & 6.0 & 300 & $120^{*}$ & 85 & 65 \\
\hline & $\mathrm{T}_{2}$ & Dec. 10 & Dec. 14 & Direct & 6.0 & 300 & $120^{*}$ & 85 & 65 \\
\hline & $\mathrm{T}_{3}$ & Dec. 10 & Dec. 14 & Direct & 6.0 & 300 & 100 & 85 & 65 \\
\hline & $\mathrm{T}_{4}$ & Dec. 10 & Dec. 14 & Direct & 6.0 & 300 & 100 & 85 & 65 \\
\hline & $\mathrm{T}_{5}$ & Dec. 10 & Dec. 14 & Direct & 6.0 & 300 & 100 & 85 & 65 \\
\hline & $\mathrm{T}_{6}$ & Dec. 10 & Dec. 14 & Direct & 6.0 & 300 & 100 & 85 & 65 \\
\hline
\end{tabular}

*Conventional farmer's rate. **Recommended by Punjab Agriculture Department, Govt. of Punjab, Pakistan

\section{Results}

\section{Plant height and leaf area index}

Maximum plant height of maize was recorded for treatment $\mathrm{T}_{5}$ which showed statistical similar response with $\mathrm{T}_{6}$ during 2014 while it was different from rest of treatments in 2015 (Table 5). For wheat, maximum plant height was recorded in treatment $\mathrm{T}_{6}$. Minimum plant height was recorded in $\mathrm{T}_{0}$ during both years for both crops. Treatments' effect was also significant on leaf area index (LAI) of both crops. Treatment $\mathrm{T}_{6}$ produced maximum LAI of maize during 2014 while it was maximum in $\mathrm{T}_{5}$ during 2015 (Table 5). The differences between treatments $\mathrm{T}_{4}, \mathrm{~T}_{5}$ and $\mathrm{T}_{6}$ were not statistically significant during both years. The LAI of wheat was higher in treatment $\mathrm{T}_{6}$ than all other treatments followed by $\mathrm{T}_{4}$, but the differences were not significant with $\mathrm{T}_{4}$ in 2015. $\mathrm{T}_{0}$ always produced minimum LAI of both crops in both growing seasons.

\section{Straw yield and grain yield}

Treatment $\mathrm{T}_{5}$ produced maximum straw yield of maize during both years. The differences among treatments were small (Table 6). The straw yield of wheat was 
higher in treatment $\mathrm{T}_{6}$ than all other treatments followed by $\mathrm{T}_{4}$ during 2014 and $\mathrm{T}_{2}$ during 2015 but the differences were not significant. Except control $\left(\mathrm{T}_{0}\right)$ all treatments differences were not significant during 2014. Table 6 shows the significance of grain yield of maize and wheat among treatments. Maximum grain yield of maize was recorded for treatment $T_{5}$ which showed statistical similar response with $T_{6}$ in 2015. Second lowest grain yield was recorded for treatment $T_{1}$ during both years. $T_{5}$ increased grain yield by 75.6 and $81.4 \%$ over that of $\mathrm{T}_{0}$ during 2014 and 2015 respectively. $\mathrm{T}_{6}$ increased grain yield of wheat by $40.7 \%$ in 2014 while $46.9 \%$ in 2015 .

Table 5. Plant height and leaf area index of maize and wheat crops under different treatments

\begin{tabular}{c|c|c|c|c|c|c|c|c}
\hline \multirow{2}{*}{ Treatments } & \multicolumn{4}{|c|}{ Plant height (cm) } & \multicolumn{4}{c}{ Leaf area index (LAI) } \\
\cline { 2 - 9 } & \multicolumn{2}{|c|}{ Maize } & \multicolumn{2}{|c|}{ Wheat } & \multicolumn{2}{c}{ Maize } & \multicolumn{2}{|c}{ Wheat } \\
\cline { 2 - 9 } & $\mathbf{2 0 1 4}$ & $\mathbf{2 0 1 5}$ & $\mathbf{2 0 1 4}$ & $\mathbf{2 0 1 5}$ & $\mathbf{2 0 1 4}$ & $\mathbf{2 0 1 5}$ & $\mathbf{2 0 1 4}$ & $\mathbf{2 0 1 5}$ \\
\hline $\mathrm{T}_{0}$ & $165.2 \mathrm{e}$ & $166.7 \mathrm{~d}$ & $80.5 \mathrm{f}$ & $78.6 \mathrm{~d}$ & $3.0 \mathrm{~d}$ & $3.0 \mathrm{c}$ & $1.4 \mathrm{~d}$ & $1.4 \mathrm{e}$ \\
$\mathrm{T}_{1}$ & $171.8 \mathrm{~d}$ & $168.4 \mathrm{~cd}$ & $84.3 \mathrm{e}$ & $94.4 \mathrm{ab}$ & $3.4 \mathrm{bc}$ & $3.4 \mathrm{~b}$ & $1.6 \mathrm{~cd}$ & $1.6 \mathrm{de}$ \\
$\mathrm{T}_{2}$ & $178.9 \mathrm{c}$ & $175.3 \mathrm{bcd}$ & $91.3 \mathrm{~cd}$ & $92.7 \mathrm{ab}$ & $3.4 \mathrm{bc}$ & $3.3 \mathrm{~b}$ & $2.0 \mathrm{~b}$ & $2.1 \mathrm{bc}$ \\
$\mathrm{T}_{3}$ & $173.1 \mathrm{~d}$ & $173.0 \mathrm{bcd}$ & $88.7 \mathrm{~d}$ & $88.1 \mathrm{bc}$ & $3.3 \mathrm{c}$ & $3.4 \mathrm{~b}$ & $1.7 \mathrm{c}$ & $1.7 \mathrm{cde}$ \\
$\mathrm{T}_{4}$ & $186.6 \mathrm{~b}$ & $177.2 \mathrm{bc}$ & $95.1 \mathrm{ab}$ & $86.1 \mathrm{c}$ & $3.6 \mathrm{ab}$ & $3.5 \mathrm{ab}$ & $2.2 \mathrm{~b}$ & $2.3 \mathrm{ab}$ \\
$\mathrm{T}_{5}$ & $190.9 \mathrm{a}$ & $191.1 \mathrm{a}$ & $92.3 \mathrm{bc}$ & $91.0 \mathrm{bc}$ & $3.6 \mathrm{abc}$ & $3.7 \mathrm{a}$ & $2.0 \mathrm{~b}$ & $2.0 \mathrm{bcd}$ \\
$\mathrm{T}_{6}$ & $180.9 \mathrm{c}$ & $182.8 \mathrm{ab}$ & $96.3 \mathrm{a}$ & $98.6 \mathrm{a}$ & $3.8 \mathrm{a}$ & $3.6 \mathrm{ab}$ & $2.4 \mathrm{a}$ & $2.5 \mathrm{a}$ \\
HSD & $\mathbf{4 . 0}$ & $\mathbf{1 0 . 1}$ & 2.9 & 6.7 & $\mathbf{0 . 3}$ & $\mathbf{0 . 3}$ & $\mathbf{0 . 3}$ & $\mathbf{0 . 4}$ \\
\hline
\end{tabular}

In single column different letters show statistical significance and same letters show non-significance at $P=0.05$. Values are shown as mean \pm standard deviation $(\mathrm{n}=3)$

Table 6. Straw yield and grain yield of maize and wheat crops under different treatments

\begin{tabular}{c|c|c|c|c|c|c|c|c}
\hline \multirow{2}{*}{ Treatments } & \multicolumn{4}{|c|}{ Straw yield $\left(\mathbf{M g ~ h a}^{-1}\right)$} & \multicolumn{4}{c}{ Grain yield (Mg ha-1) } \\
\cline { 2 - 9 } & \multicolumn{2}{|c|}{ Maize } & \multicolumn{2}{|c|}{ Wheat } & \multicolumn{2}{c}{ Maize } & \multicolumn{2}{c}{ Wheat } \\
\cline { 2 - 9 } & $\mathbf{2 0 1 4}$ & $\mathbf{2 0 1 5}$ & $\mathbf{2 0 1 4}$ & $\mathbf{2 0 1 5}$ & $\mathbf{2 0 1 4}$ & $\mathbf{2 0 1 5}$ & $\mathbf{2 0 1 4}$ & $\mathbf{2 0 1 5}$ \\
\hline $\mathrm{T}_{0}$ & $12.2 \mathrm{c}$ & $12.6 \mathrm{c}$ & $7.6 \mathrm{~b}$ & $7.4 \mathrm{c}$ & $4.0 \mathrm{~d}$ & $4.0 \mathrm{~d}$ & $2.5 \mathrm{~d}$ & $2.4 \mathrm{c}$ \\
$\mathrm{T}_{1}$ & $14.9 \mathrm{~b}$ & $15.6 \mathrm{ab}$ & $8.1 \mathrm{ab}$ & $8.1 \mathrm{abc}$ & $5.6 \mathrm{c}$ & $5.6 \mathrm{c}$ & $2.9 \mathrm{c}$ & $2.9 \mathrm{~b}$ \\
$\mathrm{~T}_{2}$ & $14.6 \mathrm{~b}$ & $16.7 \mathrm{ab}$ & $8.6 \mathrm{ab}$ & $9.6 \mathrm{ab}$ & $5.8 \mathrm{c}$ & $6.0 \mathrm{bc}$ & $3.0 \mathrm{bc}$ & $3.1 \mathrm{ab}$ \\
$\mathrm{T}_{3}$ & $16.9 \mathrm{a}$ & $17.1 \mathrm{a}$ & $7.9 \mathrm{ab}$ & $7.9 \mathrm{bc}$ & $6.0 \mathrm{c}$ & $6.5 \mathrm{ab}$ & $3.1 \mathrm{bc}$ & $3.2 \mathrm{ab}$ \\
$\mathrm{T}_{4}$ & $16.2 \mathrm{a}$ & $14.8 \mathrm{~b}$ & $9.4 \mathrm{a}$ & $8.7 \mathrm{abc}$ & $6.9 \mathrm{ab}$ & $6.7 \mathrm{ab}$ & $3.3 \mathrm{ab}$ & $3.3 \mathrm{ab}$ \\
$\mathrm{T}_{5}$ & $17.1 \mathrm{a}$ & $17.5 \mathrm{a}$ & $8.9 \mathrm{ab}$ & $8.8 \mathrm{abc}$ & $7.1 \mathrm{a}$ & $7.2 \mathrm{a}$ & $3.2 \mathrm{abc}$ & $3.2 \mathrm{ab}$ \\
$\mathrm{T}_{6}$ & $17.0 \mathrm{a}$ & $17.0 \mathrm{a}$ & $9.5 \mathrm{a}$ & $9.7 \mathrm{a}$ & $6.7 \mathrm{~b}$ & $6.8 \mathrm{ab}$ & $3.5 \mathrm{a}$ & $3.5 \mathrm{a}$ \\
HSD & $\mathbf{0 . 9}$ & $\mathbf{2 . 1}$ & $\mathbf{1 . 8}$ & $\mathbf{1 . 8}$ & $\mathbf{0 . 4}$ & $\mathbf{0 . 8}$ & $\mathbf{0 . 4}$ & $\mathbf{0 . 5}$ \\
\hline
\end{tabular}

In single column different letters show statistical significance and same letters show non-significance at $P=0.05$. Values are shown as mean \pm standard deviation $(\mathrm{n}=3)$ 


\section{Total water use and water use efficiency}

Effect of different treatments on total water use by maize was significant in both years (Table 7). Maximum water use by maize and wheat was recorded in control $\left(\mathrm{T}_{0}\right)$ treatment during both years. $\mathrm{T}_{6}$ and $\mathrm{T}_{5}$ showed minimum water use by maize and wheat crops respectively in both years. WUE differed significantly in both growing seasons. In 2014 WUE of maize ranged from $6.49 \mathrm{~kg} \mathrm{ha}^{-1} \mathrm{~mm}^{-1}$ in $\mathrm{T}_{0}$ to $11 \mathrm{~kg} \mathrm{ha}^{-1} \mathrm{~mm}^{-1}$ in $\mathrm{T}_{5}$ and from $6.61 \mathrm{~kg} \mathrm{ha}^{-1} \mathrm{~mm}^{-1}$ in $\mathrm{T}_{0}$ to $12.42 \mathrm{~kg} \mathrm{ha}^{-1} \mathrm{~mm}^{-1}$ in $\mathrm{T}_{5}$ in 2015 . WUE of maize increased by $77.7 \%$ and $87.8 \%$ in $\mathrm{T}_{5}$ as compared to that of $\mathrm{T}_{0}$ in 2014 and 2015 , respectively. The data also show that WUE of wheat increased significantly from 6.68 $\mathrm{kg} \mathrm{ha}^{-1} \mathrm{~mm}^{-1}$ in $\mathrm{T}_{0}$ to $8 \mathrm{~kg} \mathrm{ha}^{-1} \mathrm{~mm}^{-1}$ in $\mathrm{T}_{6}$ in 2014 and from $6.02 \mathrm{~kg} \mathrm{ha}^{-1} \mathrm{~mm}^{-1}$ in $\mathrm{T}_{0}$ to $8.96 \mathrm{~kg} \mathrm{ha}^{-1} \mathrm{~mm}^{-1}$ in $\mathrm{T}_{6}$ in 2015 . $\mathrm{T}_{6}$ increased WUE of wheat by 41.8 and $48.8 \%$ over that of $\mathrm{T}_{0}$ in 2014 and 2015 respectively (Table 7).

Table 7. Total water use and water use efficiency of maize and wheat crops under different treatments

\begin{tabular}{c|c|c|c|c|c|c|c|c}
\hline \multirow{2}{*}{ Treatments } & \multicolumn{4}{|c|}{ Total water use (mm) } & \multicolumn{4}{c}{ WUE $\left(\mathbf{k g ~ h a}^{-1} \mathbf{~ m m}^{-1}\right)$} \\
\cline { 2 - 9 } & \multicolumn{2}{|c|}{ Maize } & \multicolumn{2}{|c|}{ Wheat } & \multicolumn{2}{c}{ Maize } & \multicolumn{2}{c}{ Wheat } \\
\cline { 2 - 9 } & $\mathbf{2 0 1 4}$ & $\mathbf{2 0 1 5}$ & $\mathbf{2 0 1 4}$ & $\mathbf{2 0 1 5}$ & $\mathbf{2 0 1 4}$ & $\mathbf{2 0 1 5}$ & $\mathbf{2 0 1 4}$ & $\mathbf{2 0 1 5}$ \\
\hline $\mathrm{T}_{0}$ & $652.0 \mathrm{a}$ & $598.4 \mathrm{a}$ & $440.1 \mathrm{a}$ & $400.1 \mathrm{a}$ & $6.2 \mathrm{e}$ & $6.6 \mathrm{~d}$ & $5.6 \mathrm{~d}$ & $6.0 \mathrm{c}$ \\
$\mathrm{T}_{1}$ & $651.2 \mathrm{ab}$ & $581.3 \mathrm{~b}$ & $439.5 \mathrm{ab}$ & $398.6 \mathrm{ab}$ & $8.7 \mathrm{~d}$ & $9.6 \mathrm{c}$ & $6.7 \mathrm{c}$ & $7.3 \mathrm{~b}$ \\
$\mathrm{~T}_{2}$ & $649.8 \mathrm{bc}$ & $573.6 \mathrm{~d}$ & $438.8 \mathrm{bc}$ & $397.6 \mathrm{bc}$ & $8.9 \mathrm{~cd}$ & $10.5 \mathrm{bc}$ & $6.9 \mathrm{bc}$ & $7.8 \mathrm{ab}$ \\
$\mathrm{T}_{3}$ & $648.2 \mathrm{~cd}$ & $580.0 \mathrm{bc}$ & $438.1 \mathrm{~cd}$ & $397.1 \mathrm{bcd}$ & $9.2 \mathrm{c}$ & $11.3 \mathrm{ab}$ & $7.0 \mathrm{bc}$ & $8.0 \mathrm{ab}$ \\
$\mathrm{T}_{4}$ & $647.7 \mathrm{~d}$ & $573.3 \mathrm{~d}$ & $438.5 \mathrm{bc}$ & $397.4 \mathrm{bc}$ & $10.7 \mathrm{ab}$ & $11.6 \mathrm{ab}$ & $7.5 \mathrm{ab}$ & $8.4 \mathrm{ab}$ \\
$\mathrm{T}_{5}$ & $644.8 \mathrm{e}$ & $578.4 \mathrm{c}$ & $437.2 \mathrm{de}$ & $396.1 \mathrm{~cd}$ & $11.0 \mathrm{a}$ & $12.4 \mathrm{a}$ & $7.2 \mathrm{abc}$ & $8.0 \mathrm{ab}$ \\
$\mathrm{T}_{6}$ & $644.7 \mathrm{e}$ & $572.1 \mathrm{~d}$ & $436.7 \mathrm{e}$ & $395.3 \mathrm{~d}$ & $10.4 \mathrm{~b}$ & $11.9 \mathrm{a}$ & $8.0 \mathrm{a}$ & $9.0 \mathrm{a}$ \\
HSD & $\mathbf{1 . 8}$ & $\mathbf{2 . 2}$ & $\mathbf{1 . 2}$ & $\mathbf{2 . 0}$ & $\mathbf{0 . 5}$ & $\mathbf{1 . 4}$ & $\mathbf{0 . 8}$ & $\mathbf{1 . 3}$ \\
\hline
\end{tabular}

In single column different letters show statistical significance and same letters show non-significance at $P=0.05$. Values are shown as mean \pm standard deviation $(\mathrm{n}=3)$. WUE $=$ water use efficiency

\section{Soil water contents and soil water storage}

The soil water contents showed significant variation in each soil layer after harvesting under different treatments in both growing seasons (Fig. 1). In 2014 growing season of maize $\mathrm{T}_{5}$ treatment significantly increased the soil water contents in all soil layers while in 2015 growing season $\mathrm{T}_{6}$ treatment increased the soil water significantly in the upper $100 \mathrm{~cm}$ soil depth. In 120-160 cm soil layers soil water contents in $\mathrm{T}_{6}$ were lower than that at sowing. For both growing seasons of wheat, soil water contents under $\mathrm{T}_{6}$ treatment were significantly higher than that under all treatments in each soil layer. For both crops soil water contents were comparatively higher after $2^{\text {nd }}$ growing season compared with after $1^{\text {st }}$ growing season.

The soil water storage (SWS) showed slightly different pattern in both growing seasons (Fig. 2). In 2014 SWS under $\mathrm{T}_{6}$ was higher throughout the growing season of maize except in middle of season where SWS was comparatively lower. In wheat season SWS in $\mathrm{T}_{6}$ treatment was initially lower but it remained higher for rest of season. In 2015, SWS in $\mathrm{T}_{6}$ treatment was higher throughout the maize growing season. In 
wheat season SWS in $\mathrm{T}_{6}$ treatment was lower in start and middle of growing season while it was higher during late stages of growing season. SWS was comparatively lower in $\mathrm{T}_{0}$ for both crops except 2014 growing season of wheat in which SWS was lower in $\mathrm{T}_{2}$ at the end of season.
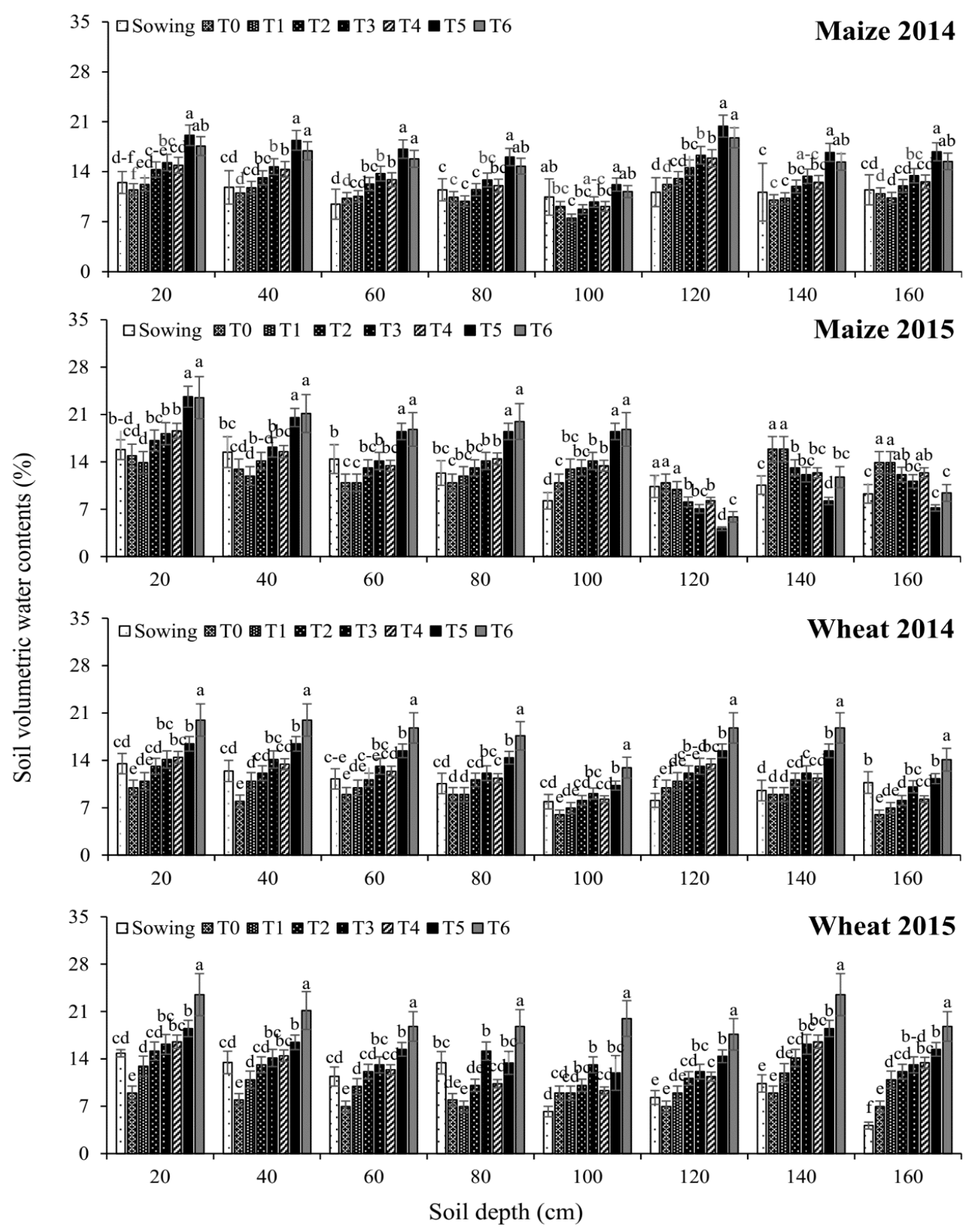

Figure 1. Soil water contents before sowing and harvesting of maize-wheat crops under different treatments. Bars represent standard deviation $(n=3)$. Column with different letters within same depth are statistically significant at $P=0.05$ 

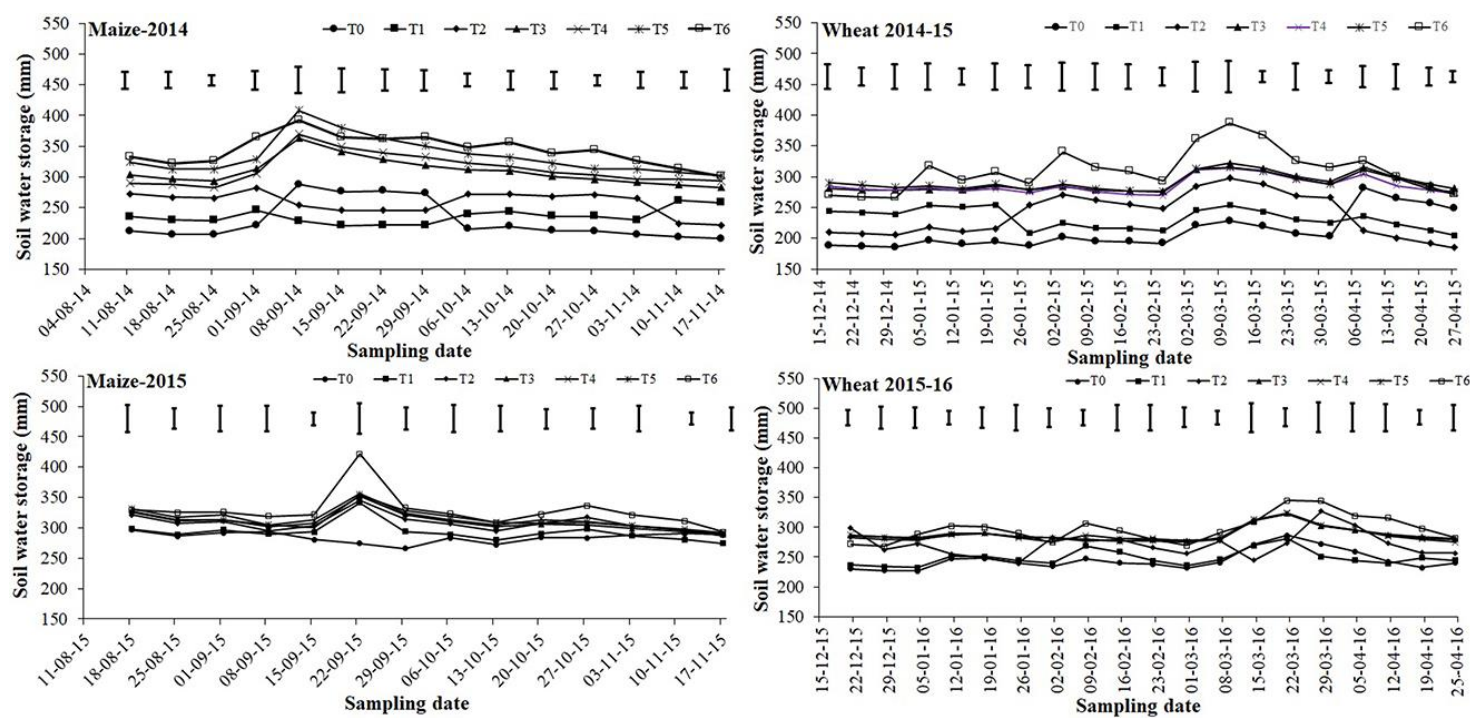

Figure 2. Soil water storage under different treatment in maize and wheat growing seasons.

Bars represent $H S D_{0.05}$ values

\section{Soil active carbon and bulk density}

Figure 3 shows that mulches significantly decreased the soil bulk density in upper and lower soil layers. Treatment $\mathrm{T}_{6}$ resulted in lower bulk density in both soil layers after harvest of maize and wheat.

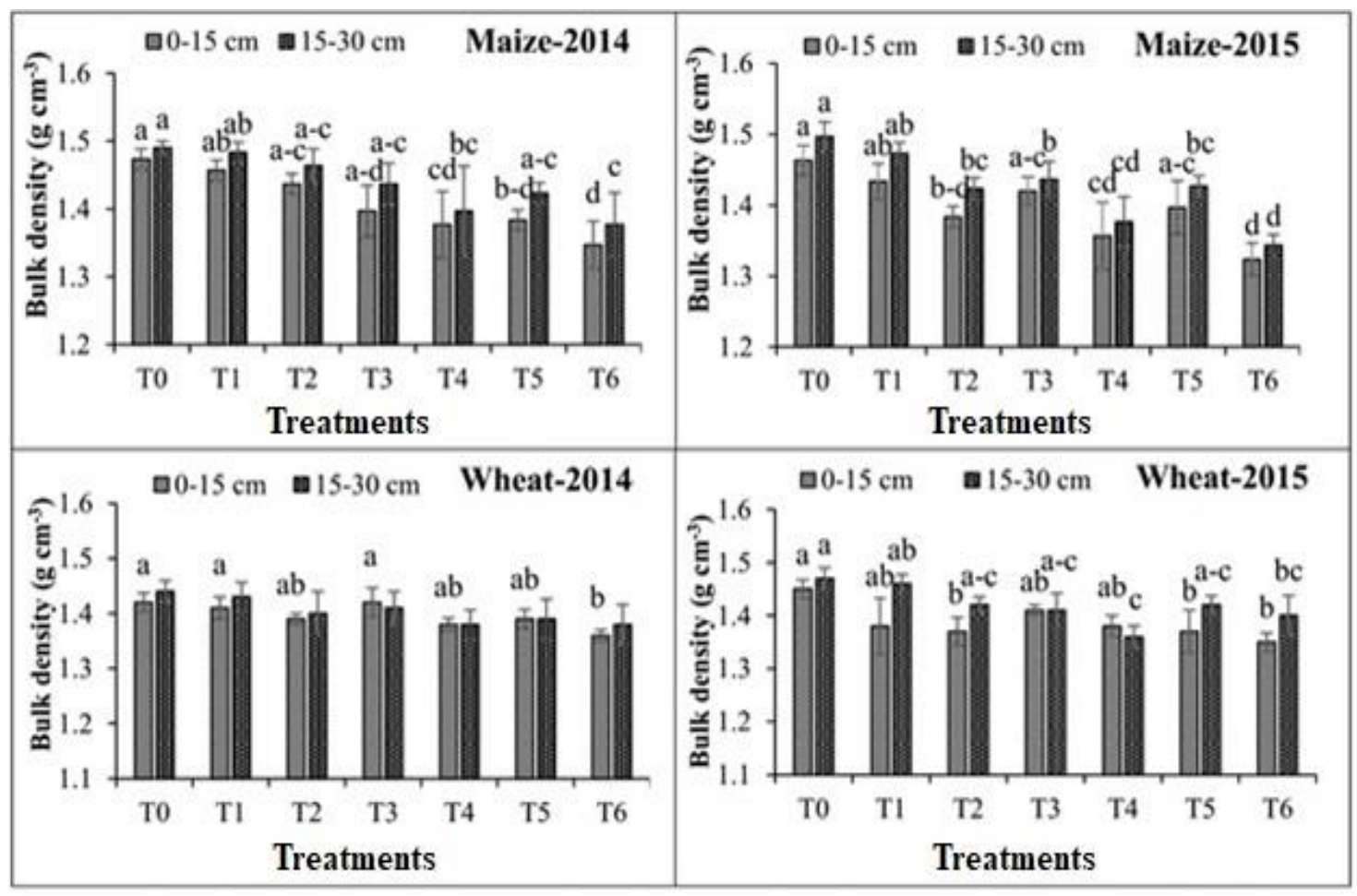

Figure 3. Soil bulk density under different treatments after maize and wheat harvest. Bars represent standard deviation $(n=3)$. Column with different letters within same year and depth are statistically significant at $P=0.05$ 
Upper soil layer $(0-15 \mathrm{~cm})$ exhibited lower bulk density than that of lower soil layer $(15-30 \mathrm{~cm})$. Active carbon content decreased with increase in soil depth during both years after harvest of both crops (Fig. 4). Significantly higher active carbon contents were recorded in $T_{6}$ followed by $T_{4}$. However, difference between $T_{6}$ and $T_{4}$ was not significant in both soil layers in both growing seasons. In surface as well as sub-surface soil layers $\mathrm{T}_{0}$ resulted in higher bulk density and lower active carbon contents during both years.
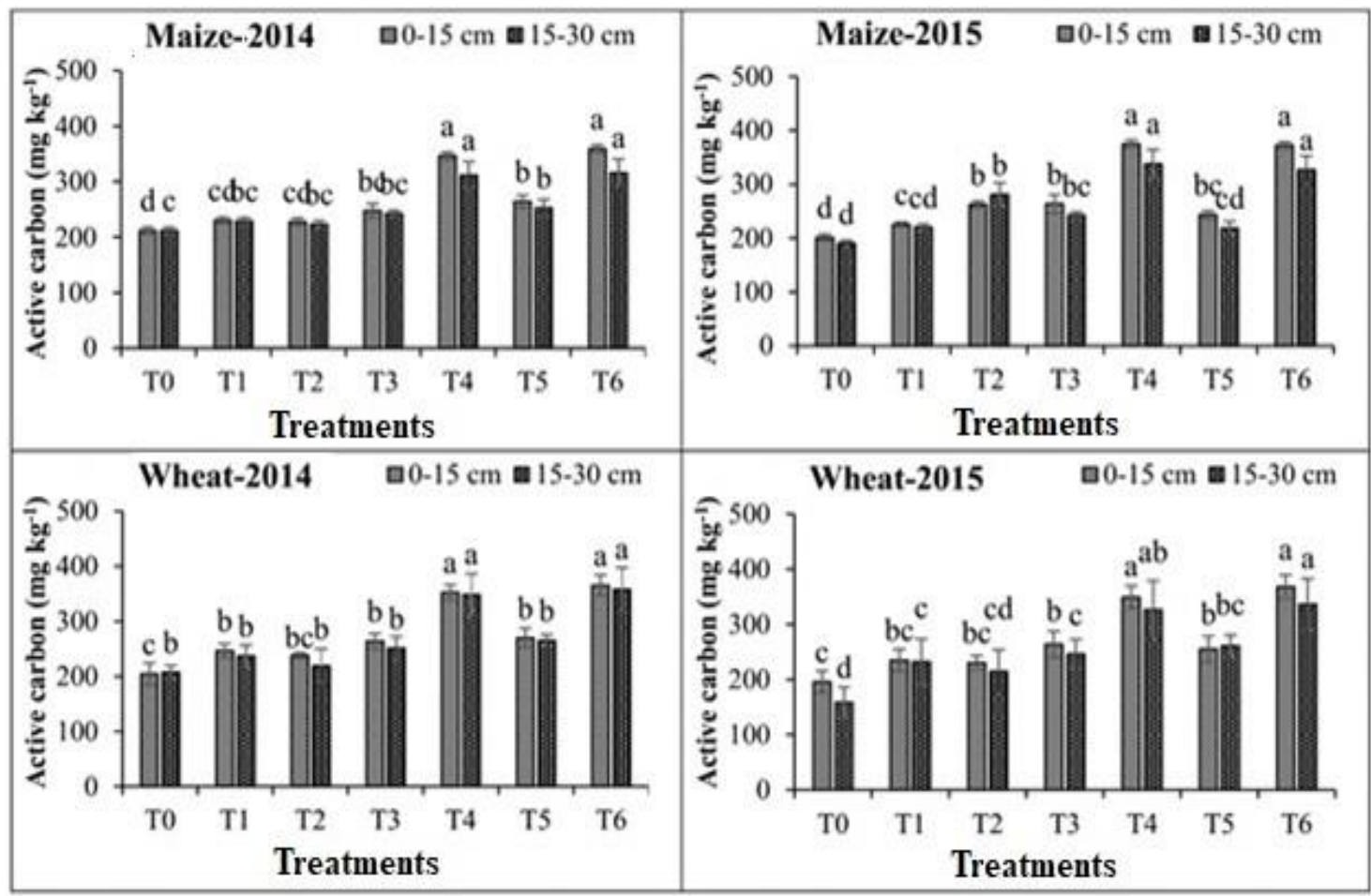

Figure 4. Soil active carbon content under different treatments after maize and wheat harvest. Bars represent standard deviation $(n=3)$. Column with different letters within same year and depth are statistically significant at $P=0.05$

\section{Discussion}

If nutrients status of soil especially nitrogen is poor the plant water use may be low and mulches effects may not be ideal even if the mulches are properly applied. Plants use nitrogen as an essential macronutrient to produce large number of complex macromolecules like proteins, amino acids and nucleic acids that play a vital role for their life cycles (Mengel and Kirkby, 2001). For improved crop yield and WUE, a proper and balanced supply of nitrogen from soil is essentially required which helps plants for better root and shoot growth (Ali and Talukder, 2008). A huge gap exists between nitrogen supply and demand by plants as almost all of soils in the world are deficient in nitrogen. In many conventional and low input farming systems nitrogen supply is still limited which is reducing the crop production. Therefore, nitrogen fertilization has been termed as main priority for supplying nutrients. This is particularly true for maize and wheat which are major consumers of nitrogen fertilizers.

Although increased crop yield is the main objective of nitrogen fertilizers and have never been termed as water conservation practice, it has very important role in 
increasing the amount of water use by plants. In our study $\mathrm{N}$ fertilization and mulching significantly increased the yield of maize-wheat crops (Table 6). Mulching and $\mathrm{N}$ fertilizer application conserved the soil water which significantly increased the WUE, and this was the main reason of increased crop yield. Mulching materials, especially $\mathrm{T}_{5}$ and $\mathrm{T}_{6}$ treatments, showed a higher potential for improving maize and wheat yield respectively as compared to unmulched treatment. Levels of nitrogen fertilizer affect the sensitivity of maize and wheat crops to water stress as reported in previous studies (Gheysari et al., 2009) and increase in nitrogen inputs increased the WUE of maize (Paolo and Rinaldi, 2008). In our study, applying $\mathrm{N}$ fertilizer significantly increased WUE, but the difference was significant between mulched and unmulched treatments. Liu et al. (2014b) reported a significant negative correlation between WUE and level of nitrogen fertilizer. Mulching treatments, including the $\mathrm{T}_{5}$ and $\mathrm{T}_{6}$ treatments, significantly increased the WUE of maize and wheat respectively compared to the unmulched treatment which might be attributed to the decrease in evaporation and the increased water retention due to surface application of mulches, i.e. straw or plastic film (Li et al., 2013). Interaction effect of mulches and nitrogen was more significant for maize-wheat yield and WUE in second year (Table 6).

The results of present studies clearly highlight the importance of nitrogen management for both maize and wheat crops to improve their growth and yield and to conserve water in soil. In addition to improving the growth and yield of maize and wheat, reduction of water evaporation from soil surface by the combined use of mulches and nitrogen might be the major reasons of improved WUE of both maize and wheat. A significant relationship exists between mulching and nitrogen that affect the crop yield and WUE (Liu et al., 2017) which might be the reason of improved yield and WUE of maize and wheat crops in present study. Coupling effects of mulching and nitrogen were significant on WUE because mulching improves the nitrogen uptake by altering the water use by maize and wheat crops (Liu et al., 2016). The interaction effect of mulches and nitrogen becomes more significant with time which supports that longterm field experiments are needed to determine this effect on yield and WUE of maize and wheat crops (Dong et al., 2014).

A significant correlation was found between soil active carbon and WUE of both maize and wheat crops in our study (Fig. 5). The soil active carbon contents were linearly correlated with WUE of maize $(\mathrm{r}=0.71, P<0.01$ in 2014 and $\mathrm{r}=0.59$, $P<0.05$ in 2015) and wheat $(\mathrm{r}=0.87, P<0.01$ in 2014 and $\mathrm{r}=0.89, P<0.01$ in 2015). This explains the significance of mulching in improving WUE. Improvement in WUE by active carbon is due to improvement in soil quality by increasing organic carbon (Shehzadi et al., 2017). The results indicate that application of straw mulch significantly improved the soil properties as compared to plastic film in both maize and wheat crops under similar nitrogen treatment. Improved soil fertility and soil properties have been well documented by the application of straw mulches that in turn affect crop growth and yield (Mulumba and Lal, 2008; Saroa and Lal, 2003). Soil organic matter increases by the application of straw mulch (Saroa and Lal, 2003) and this increase in soil organic matter improves aggregate stability of soil (Mulumba and Lal, 2008) and soil porosity and as a result water infiltration rate is also improved (Edwards et al., 2000). Nzeyimana et al. (2017) reported that straw mulch significantly decreased the soil bulk density and improved the organic carbon and soil aggregate stability. In the surface soil layer, significant increase in soil organic matter and reduction in bulk density have been 


$$
-7407 \text { - }
$$

widely reported (Singh et al., 2007; Yadvinder-Singh et al., 2009) and similar results have also been obtained in current study.

Soil organic carbon increased by straw mulch in surface soil layer is an energy source for microorganisms in soil (Tebrugge and During, 1999) which improves soil porosity with a decrease in bulk density through bioturbation (Mulumba and Lal, 2008). Soil aeration and root growth is improved by increased soil porosity which in result in improved crop development (Six et al., 2000) and nutrients and water uptake is also improved. The results are in agreement with those of Nawaz et al. (2017) who reported the beneficial role of mulches in improving soil organic carbon and total soil porosity with a decrease in soil bulk density compared with no mulch. Treatments $\mathrm{T}_{5}$ and $\mathrm{T}_{6}$ conserved more soil water during both growing seasons of maize and wheat crops. This increase in soil water storage is explained by increase in active carbon contents in soil which increased the water holding capacity of soil. This shows that mulching has good potential in increasing soil water storage and soil organic carbon. Increase in soil water contents with increase in soil organic carbon has also been reported by Minasny and Mcbratney (2018) and Qureshi et al. (2010).
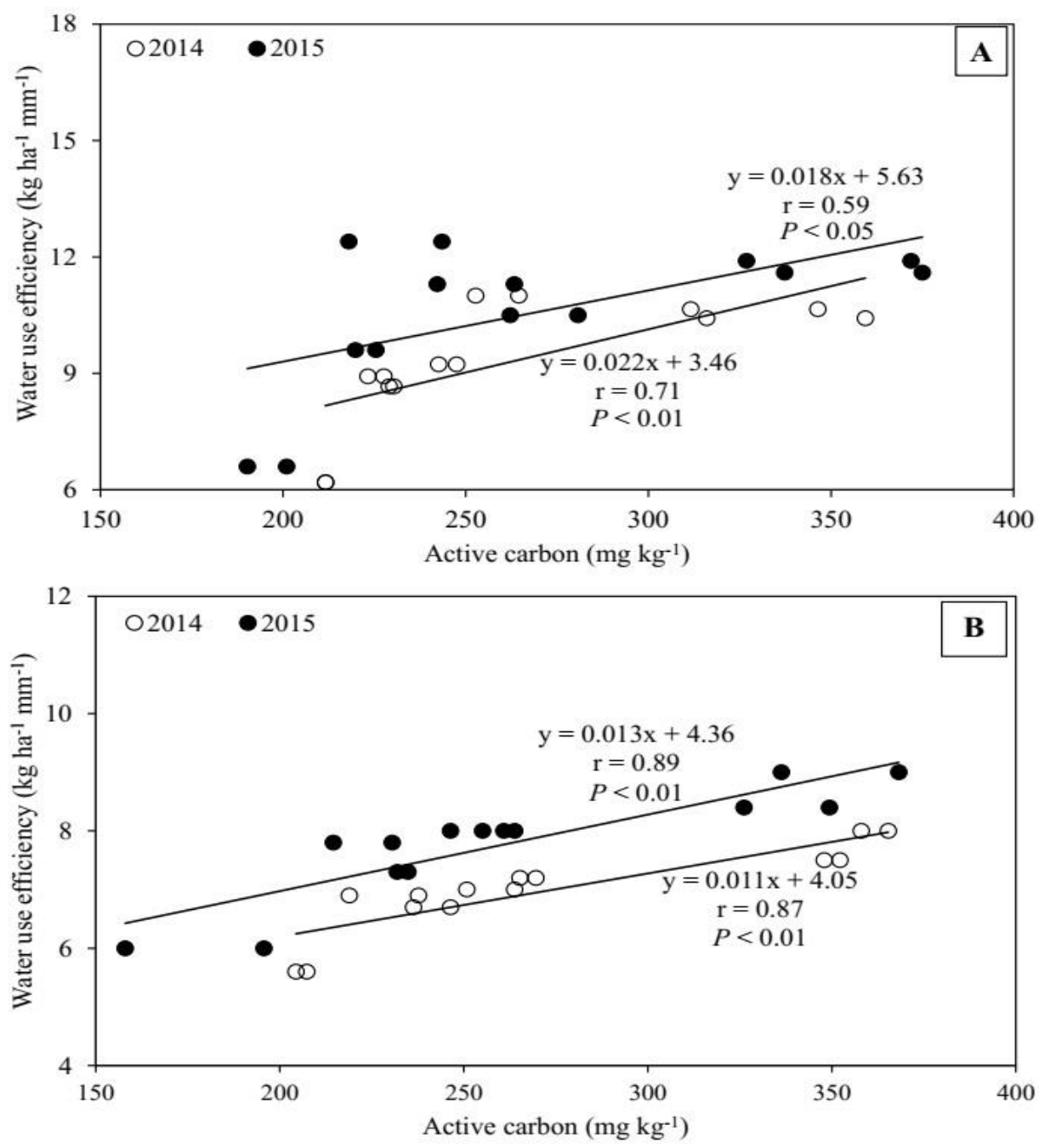

Figure 5. Correlation between soil active carbon in $0-30 \mathrm{~cm}$ soil layer and water use efficiency of maize $(A)$ and wheat $(B)$ in two growing seasons 
The findings clearly show that overall mulches performed well in terms of WUE and soil carbon with addition of nitrogen. Apparently, plastic and rice straw mulches have positive effects and results of current study indicate that use of these mulches can increase maize and wheat yield significantly. However, high labor cost, unavailability of proper straw mulch and difficulties in collection and recycling of plastic film residues are some side-effects of mulching. Therefore, site specific conditions and these sideeffects must be included in guidelines for recommending mulch practices.

\section{Conclusion}

Nitrogen applied in three splits under plastic film for maize and under straw mulch for wheat significantly improved growth and yield of respective crops. Nitrogen fertilization under mulched conditions significantly decreased the total water use and increased the WUE in both crops. The effects of mulching were more pronounced with increased splits of nitrogen. The results of experiments contribute to our knowledge of soil surface mulching and $\mathrm{N}$ fertilization effects on crop growth and WUE. Nitrogen (200 kg ha ${ }^{-1}$ for maize and $100 \mathrm{~kg} \mathrm{ha}^{-1}$ for wheat) should be applied in three splits for both maize and wheat crops under mulched conditions. Farmer's nitrogen application rates $\left(250 \mathrm{~kg} \mathrm{ha}^{-1}\right.$ for maize and $120 \mathrm{~kg} \mathrm{ha}^{-1}$ for wheat) are overuse and this rate can be decreased by mulching. Therefore, mulching should be practiced considering the nitrogen inputs and crop type. In addition, these findings may be helpful to optimize management practices (mulches and nitrogen) to improve crop production and at the same time improve soil quality in semi-arid cropping system.

Acknowledgements. This work is a part of Ph.D. Dissertation and supported by the Higher Education Commission of Pakistan (315-246-2AV3-001).

\section{REFERENCES}

[1] Ahmad, M. U. D., Masih, I., Giordano, M. (2014): Constraints and opportunities for water savings and increasing productivity through resource conservation technologies in Pakistan. - Agriculture, Ecosystem and Environment 187: 106-115.

[2] Ali, M. H., Talukder, M. S. U. (2008): Increasing water productivity in crop production a synthesis. - Agricultural Water Management 95: 1201-1213.

[3] Blake, G. R., Hartge, K. H. (1986): Bulk Density. - In: Klute, A. (ed.) Methods of Soil Analysis. Part I. Agron. 9. ASA, Madison, WI, USA, pp. 363-375.

[4] Chakraborty, D., Nagarajan, S., Aggarwal, P., Gupta, V. K., Tomar, R. K., Garg, R. N., Sahoo, R. N., Sarkar, A., Chopra, U. K., Sarma, K. S. S., Kalra, N. (2008): Effect of mulching on soil and plant water status, and the growth and yield of wheat (Triticum aestivum L.) in a semi-arid environment. - Agricultural Water Management 95: 13231334.

[5] Dong, W. Y., Zhang, X. Y., Dai, X. Q., Fu, X. L., Yang, F. T., Liu, X. Y., Sun, X. M., Wen, X. F., Schaeffer, S. (2014): Changes in soil microbial community composition in response to fertilization of paddy soils in subtropical China. - Applied Soil Ecology 84: 140-147.

[6] Dwyer, L. M., Stewart, D. W. (1986): Leaf area development in field-grown maize. Agronomy Journal 78: 334-343. 
[7] Edwards, L., Burney, J. R., Richter, G., MacRae, A. H. (2000): Evaluation of compost and straw mulching on soil-loss characteristics in erosion plots of potatoes in Prince Edward Island, Canada. - Agriculture, Ecosystem and Environment 81: 217-222.

[8] Fang, Q. X., Ma, L., Green, T. R., Yu, Q., Wang, T. D., Ahuja, L. R. (2010): Water resources and water use efficiency in the North China Plain: Current status and agronomic management options. - Agricultural Water Management 97: 1102-1116.

[9] Farooq, M., Nawaz, A. (2014): Weed dynamics and productivity of wheat in conventional and conservation rice-based systems. - Soil and Tillage Research 141: 1-9.

[10] Gheysari, M., Mirlatifi, S. M., Homaee, M., Asadi, M. E., Hoogenboom, G. (2009): Nitrate leaching in a silage maize field under different irrigation and nitrogen fertilizer rates. - Agricultural Water Management 96: 946-954.

[11] Green, T. R., Yu, Q. A., Ma, L. W., Wang, T. D. (2010): Crop water use efficiency at multiple scales. - Agricultural Water Management 97: 1099-1101.

[12] Huai, H. J., Zhang, H. L., Cai, W. T., Chen, F. (2009): Effect of different nitrogen rates on nitrogen utilization and residual soil nitrate of spring maize. - Journal of AgroEnvironment Science 28(12): 2651-2656.

[13] Jabran, K., Ullah, E., Hussain, M., Farooq, M., Zaman, U., Yaseen, M., Chauhan, B. S. (2015): Mulching improves water productivity, yield and quality of fine rice under watersaving rice production systems. - Journal of Agronomy and Crop Science 201(5): 389400 .

[14] Kader, M. A., Sengeb, M., Mojidc, M. A., Ito, K. (2017): Recent advances in mulching materials and methods for modifying soil environment. - Soil and Tillage Research 168: 155-166.

[15] Kettering, J., Ruidisch, M., Gaviria, C., Ok, Y., Kuzyakov, Y. (2013): Fate of fertilizer ${ }^{15} \mathrm{~N}$ in intensive ridge cultivation with plastic mulching under a monsoon climate. Nutrient Cycling in Agroecosystems 95: 57-72.

[16] Khan, A. U. H., Iqbal, M., Islam, K. R. (2007): Dairy manure and tillage effects on soil fertility and corn yields. - Bioresource Technology 98: 1972-1979.

[17] Li, S. X., Wang, Z. H., Hu, T. T., Gao, Y. J., Stewart, B. A. (2009): Nitrogen in dryland soils of China and its management. - Advances in Agronomy 101: 123-181.

[18] Li, S. X., Wang, Z. H., Li, S. Q., Gao, Y., Tian, X. H. (2013): Effect of plastic sheet mulch, wheat straw mulch, and maize growth on water loss by evaporation in dryland areas of China. - Agricultural Water Management 116: 39-49.

[19] Li, X. Y., Gong, J. D., Wei, X. H. (2000): In-situ rainwater harvesting and gravel mulch combination for corn production in the dry semi-arid region of China. - Journal of Arid Environments 46: 371-382.

[20] Liu, C. A., Zhou, L. M., Jia, J. J., Wang, L. J., Si, J. T., Li, X., Pan, C. C., Siddique, K. H. M., Li, F. M. (2014b): Maize yield and water balance is affected by nitrogen application in a film-mulching ridge-furrow system in a semiarid region of China. - European Journal of Agronomy 52: 103-111.

[21] Liu, J. L., Bu, L., Zhu, L., Luo, S., Chen, X., Li, S. (2014a): Optimizing plant density and plastic film mulch to increase maize productivity and water-use efficiency in semiarid areas. - Agronomy Journal 106: 138-1146.

[22] Liu, Q., Chen, Y., Liu, Y., Wen, X., Liao, Y. (2016): Coupling effects of plastic film mulching and urea types on water use efficiency and grain yield of maize in the Loess Plateau, China. - Soil and Tillage Research 157: 1-10.

[23] Liu, X. Y., Ju, X. T., Zhang, L. J., Li, X. Y., Liu, L. J. (2010): Effects of different N rates on fate of $\mathrm{N}$ fertilizer and balance of soil $\mathrm{N}$ of winter wheat. - Plant Nutrition and Fertilizer Science 16(2): 296-303.

[24] Liu, Z., Meng, Y., Cai, M., Zhou, J. (2017): Coupled effects of mulching and nitrogen fertilization on crop yield, residual soil nitrate, and water use efficiency of summer maize in the Chinese Loess Plateau. - Environmental Science and Pollution Research 24: 25849-25860. 
[25] Meng, Q. F., Sun, Q. P., Chen, X. P., Cui, Z. L., Yue, S. C., Zhang, F. S., Römheld, V. (2012): Alternative cropping systems for sustainable water and nitrogen use in the North China Plain. - Agriculture, Ecosystem and Environment 146: 93-102.

[26] Mengel, K., Kirkby, E. A. (2001): Principles of Plant Nutrition, 5th ed. - Kluwer Academic Publisher, Dordrecht/Boston/London, pp. 161-175.

[27] Minasny, B., Mcbratney, A. B. (2018): Limited effect of organic matter on soil available water capacity. - European Journal of Soil Science 69: 39-47.

[28] Mulumba, L. N., Lal, R. (2008): Mulching effects on selected soil physical properties. Soil and Tillage Research 98: 106-111.

[29] Nawaz, A., Lal, R., Shrestha, R. K., Farooq, M. (2017): Mulching affects soil properties and greenhouse gas emissions under long-term no-till and plough-till systems in Alfisol of Central Ohio. - Land Degradation and Development 28: 673-681.

[30] Nzeyimana, I., Hartemink, A. E., Ritsema, C., Stroosnijder, L., Lwanga, E. H., Geissen, V. (2017): Mulching as a strategy to improve soil properties and reduce soil erodibility in coffee farming systems of Rwanda. - Catena 149: 43-51.

[31] Paolo, E. D., Rinaldi, M. (2008): Yield response of corn to irrigation and nitrogen fertilization in a Mediterranean environment. - Field Crop Research 105: 202-210.

[32] Pervaiz, M. A., Iqbal, M., Shahzad, K., Hassan, A. U. (2009): Effect of mulch on soil physical properties and $\mathrm{N}, \mathrm{P}, \mathrm{K}$ concentration in maize (Zea mays L.) shoots under two tillage systems. - International Journal of Agriculture and Biology 11: 119-124.

[33] Qureshi, A. S., McCornick, P. G., Sarwar, P. G., Sharma, B. R. (2010): Challenges and prospects for sustainable management in the Indus Basin, Pakistan. - Water Resources Management 24(1): 1551-1569.

[34] Ram, H., Dadhwal, V., Vashist, K. K., Kaur, H. (2013): Grain yield and water use efficiency of wheat (Triticum aestivum L.) in relation to irrigation levels and rice straw mulching in North West India. - Agricultural Water Management 128: 92-101.

[35] Saroa, G. S., Lal, R. (2003): Soil restorative effects of mulching on aggregation and carbon sequestration in a Miamian soil in Central Ohio. - Land Degradation and Development 14: 481-493.

[36] Shehzadi, S., Shah, Z., Mohammad, W. (2017): Impact of organic amendments on soil carbon sequestration, water use efficiency and yield of irrigated wheat. - Biotechnology, Agronomy, Society and Environment 21(1): 36-49.

[37] Singh, G., Jalota, S. K., Yadvinder-Singh. (2007): Manuring and residue management effects on physical properties of a soil under the rice-wheat System in Punjab, India. Soil and Tillage Research 94: 229-238.

[38] Six, J., Elliott, E. T., Paustian, K. (2000): Soil macroaggregate turnover and microaggregate formation: A mechanism for $\mathrm{C}$ sequestration under no tillage agriculture. - Soil Biology and Biochemistry 32: 2099-2103.

[39] Soil Survey Staff (2014): Keys to Soil Taxonomy. $12^{\text {th }}$ ed. - USDA-NRCS, Washington, DC, USA.

[40] Steel, R. G. D., Torrie, J. H., Dickey, D. (1997): Principles and Procedures of Statistics. A Biometrical Approach. 3rd ed. - McGraw Hill Book Co. Inc., New York, USA, pp. 172-177.

[41] Su, Z. Y., Zhang, J. S., Wu, W. L., Cai, D. X., Lu, J. J., Jiang, G. H., Huang, J., Gao, J., Harmann, R., Gabriels, D., 2007. Effects of conservation tillage practices on winter wheat water-use efficiency and crop yield on the Loess Plateau, China. - Agricultural Water Management 87: 307-314.

[42] Tebrugge, F., During, R. A. (1999): Reducing tillage intensity: A review of results from a long tern study in Germany. - Soil and Tillage Research 53: 15-28.

[43] Topp, G. C., Galganov, Y. T., Ball, B. C., Carter, M. R. (1993): Soil Water Desorption Curves. - In: Carter, M. R. (ed.) Soil Sampling and Methods of Analysis. Canadian Society of Soil Science. Lewis Publishers, Boca Raton, FL., USA, pp. 569-579. 
[44] UN (United Nations, Department of Economic and Social Affairs, Population Division) (2017): World Population Prospects: The 2017 Revision. - United Nations, New York.

[45] Vitousek, P. M., Naylor, R., Crews, T., David, M. B., Drinkwater, L. E., Holland, E., Johnes, P. J., Katzenberger, J., Martinelli, L. A., Matson, P. A., Nziguheba, G., Ojima, D., Palm, C. A., Robertson, G. P., Sanchez, P. A., Townsend, A. R., Zhang, F. S. (2009): Nutrient imbalances in agricultural development. - Science 324: 1519-1520.

[46] Weil, R. R., Islam, K. R., Stine, M. A., Gruver, J. B., Samson-Liebig, S. E. (2003): Estimating active carbon for soil quality assessment: A simplified method for laboratory and field use. - American Journal of Alternative Agriculture 18: 3-17.

[47] Yadvinder-Singh, Gupta, R. K., Gurpreet-Singh, Jagmohan-Singh, Sidhu, H. S., BijaySingh (2009): Nitrogen and residue management effects on agronomic productivity and nitrogen use efficiency in rice-wheat system in Indian Punjab. - Nutrient Cycling in Agroecosystems 84: 141-154.

[48] Zhang, X. Y., Chen, S. Y., Liu, M. Y., Pei, D., Sun, H. Y. (2005): Improved water use efficiency associated with cultivars and agronomic management in the North China Plain. - Agronomy Journal 97: 78-790. 